\title{
Satisfaction and Loyalty of Clients towards Banking Products and Services
}

\author{
Milica Raičević $^{1 *}$ | Dijana Medenica Mitrović ${ }^{2}$ \\ 1 Mediterranean University, Faculty of Economics and Business, Podgorica, Montenegro \\ 2 Faculty for Business Management, Bar, Montenegro
}

\begin{abstract}
Transformation of the banking sector has led to today's banks providing a complete service - financial service both on the domestic and international level. The focus of their business is the client whose loyalty depends on the operations of the bank. The aim is to indicate that there is a direct link between the quality of the banking product and the service that affects the client's satisfaction and loyalty, which directly affects the bank's business and its competitive advantage in the financial market. The paper gives a theoretical and practical overview of the quality of service, satisfaction and loyalty of clients, and the performance of the bank, which depends on clients. In the theoretical part, the concept of a client, its significance and specifics related to its influence on the bank's business, through its satisfaction and loyalty to the bank, is defined. The empirical part deals with the analysis of customer satisfaction and loyalty towards banking products and services in Montenegro and how much the quality of banking services has an impact on the satisfaction and loyalty of the customer. The analysis of the factual situation will be carried out, the conclusions will be presented and recommendations made for improvement of the quality of the service, which will contribute to the greater satisfaction of the clients, and therefore the loyalty to the particular bank. All of this is directly related to the possibility of achieving the competitive advantage of banks within the banking sector where a particular bank operates.
\end{abstract}

Key words: Quality of service, satisfaction, loyalty, client, banking sector, strategic management

JEL Classification: J5, E5

\section{INTRODUCTION}

In the business world, there is a "fight" around every potential but also a permanent client. Services are a key segment in achieving these goals. If we have a good placement of products and services, and most importantly, if we take care of the client and his needs, we can gain his loyalty. This is precisely the key to the success of banks, because a loyal client is satisfied with the client, and therefore the bank has secured the advantage of the bank and a secure profit. Banks through the perception of quality perception by clients can improve their business and offer a better and better service that is tailored to the needs of clients. What contributes to satisfaction is building full loyalty among bank clients because clients are hitting propaganda messages that try to influence their perception. Thus, when creating a service, account must be taken of the heterogeneity of the market and service supply gaps, i.e. the difference between the expectations of consumers and their perception of the delivered service (Hill, 2006) and must achieve superior value for the consumer (Marinković, 2012). Consequently, the quality system of services becomes a lever that prevents attempts to influence customer satisfaction and loyalty. In this way, the

\footnotetext{
*Corresponding Author, e-mail: milica.raicevic@unimediteran.net
} 
quality and comprehensiveness of the service is the best tool for building a sense of loyalty with banking clients.

The methodology of the work includes a theoretical and practical overview of the importance and role of the quality of services, satisfaction and loyalty of clients towards banking products and services, and hence the success of the bank itself. Theoretical part defines the concept of the client, his / her significance and specific features related to his / her influence on the operations of the bank, through his / her satisfaction and loyalty to the bank.

The empirical part deals with the analysis of client's satisfaction and loyalty for banking products and services in Montenegro and how much quality of banking services affects the satisfaction and loyalty of the client. Based on the collected data, will be carried out an analysis of the factual situation, the conclusions will be drawn and recommendations made to improve the quality of the service, which will contribute to the greater satisfaction of the clients, and therefore the loyalty towards the specific bank

The initial hypotheses of the paper read:

H0: The quality of banking operations has a crucial role in the process of building long-term relationships with consumers. Only satisfied clients are loyal clients, who make it possible for the bank to achieve long-term business goals and make profit.

H1: By improving the quality of products and services, the mutual relationship between the client and the bank is improved, as well as the business environment in which both parties take part.

H2: By improving the quality of banking services, a competitive advantage is achieved and the position of banks in the financial market strengthens, especially considering that banks operating in an environment which is rapidly changing.

The aim of the paper is to determine whether the clients are satisfied with the quality of banking products and services, as well as in which part of the relationship there is customer dissatisfaction and how banks should act to dissatisfy dissatisfaction. Only a satisfied client is a loyal client. Improving the quality of mutual relations, improving the business environment, and contributing to the creation of a competitive advantage of the bank in the financial market.

\section{THEORY ASPECTS OF THE ORIENTATION ON THE LOYALTY OF THE CLIENT AND THE QUALITY OF SERVICES}

\section{Relationship between the client and the quality of banking products and services}

Each market and thus the banking sector consists of two main players - bank and client (Raicevic, Medenica-Mitrovic, 2018). On this relationship between these two actors there is a service that provides a satisfied client on the one hand, and on the other, a satisfied bank. Satisfied customer satisfaction with the product and service manifested by loyalty, and the company is even better service. On the path of defining the "complete service" of the questions to be answered, according to Baker (Vasiljev, 1999) that the client would be satisfied and, in the future, he was loyal to the services of the given company: Which goods and services should be produced and in what quantities? How to produce (resources and technology)? For whom to produce? This third question, by market research, leads us to the client's profile who buys or will buy our products and services. The goal of clients is to fulfill their needs for a specific product and service with the easiest and fastest way, with the least cost. This leads us to questions about the cost of the cost, and why and on what basis the client for a product or service is prepared to pay more, what are the "value components" of the product or service, and what is the most important for the buyer in purchasing (Maričić, 2005). What we need to keep in mind when creating products and services is the fact that the client and his satisfaction are the most important for the company because the company depends on the client, that the client is the purpose of the company's existence (Kotler, 
1999) and that, based on his wishes, we create products and services and marketing activities, i.e. product synthesis, pricing, access, distribution channels and at the end of the promotion, we want to satisfy the client who will come again. Thus, a company creates a loyal customer on the one hand, and on the other provides him with a competitive advantage and a secure profit.

A satisfied customer is not a sufficient guarantee of success at work. What distinguishes successful companies today from unsuccessful is the phenomenon of customer loyalty (Zelenović, 2015). A prerequisite for the formation of consumer loyalty is satisfaction with the product or service. If consumers are not satisfied on any basis, loyalty cannot be achieved. The more loyal consumer is the one who is absolutely satisfied with the product and the service, and the company is more important than the one who is just satisfied. It is considered that a completely satisfied client is a precondition for forming loyalty and strengthening relations with the company in the long run. The customer's first impression is very important - it is crucial to achieve customer satisfaction at the first meeting, in order to have the basis for the formation of loyalty. Client demands, needs and expectations represent a basic basis that enables the establishment of appropriate relationships on a client-to-client relationship in order to create good conditions for creating satisfaction, which is the main means of creating long-term consumer loyalty (Rajola, 2004).

Thus, according to Veljković (2004), all clients could be divided into four categories: absolute loyalty, unstable loyalty, relative loyalty and disloyalty. Each market consists of these four segments of consumers, according to the degree of loyalty. For each company, it is very important that as many consumers are in the category of absolutely loyal. Only an absolutely loyal consumer is a security for the company, that is, only such consumers will, in the long terms, be faithful to company and its services.

\section{Satisfaction and loyalty of clients towards banking products and services}

Loyalty can be defined as an attitude towards a particular brand, which results in a constant purchase over time. The service that the company markets on the market depends on consumer loyalty, so it is very important that close and effective communication is achieved with existing and potential clients. Implementation of the loyalty program has a positive trend in our country as well. They are increasingly applied, and more and more companies are introducing, innovating, expanding, creating new channels of communication with consumers, but also allowing buyers to influence the creation of a range of products and services with their advice, wishes and suggestions in order to achieve long-term satisfaction. Depending on the frequency of repeated purchases and the intensity of attitudes towards a particular brand, it is possible to identify four types of loyalty, according to Veljković, which are (Veljković, 2009): false loyalty, latent loyalty, stable loyalty and no loyalty. Establishing a quality and long-term relationship with the client is a concept that has turned into a special business philosophy in the banking sector in the last decade. This approach implies putting the client in the center of business processes and planning based on an analysis of his needs, which in practical terms means a good knowledge of clients, as well as providing a timely response to their demands (Gaborović, 2009). Banks are struggling to adapt their service to the aforementioned concept on multiple levels in order to achieve a high quality relationship with customers. First of all, a good relationship with the client begins with the first contact in the branch office, where during a well planned meeting, the bank officials try to determine the client's profile and, on the basis of the information obtained at that time, prepare the appropriate offer of products and services. The offer should be in line with the client's financial capabilities, needs and plans for the future.

The highest level of quality relationship with clients, which gives full meaning to the principle of "putting the customer at the center of attention", is the Customer Relationship Management, which, in addition to the above, implies a proactive relationship with the client and a response to his needs prepared on the basis of the acquired knowledge of the client, through profiling and 
analysis (Hanić, Domazet, 2012) (Hanić, Domazet, Drašković, 2011). By applying this method, the bank approaches the client by offering him services and products that suit his profile - style of life, occupation, and even habits and interests. In this way, a long-term relationship with clients is guaranteed that meets the interests of both sides. Customer Relationship Management (CRM) or Customer Relationship Management is an approach to managing the company through interaction with current and future consumers (Jovićević, Žugić, 2018). The CRM approach analyzes customer data and their history with the company, in order to improve business relationships with customers / customers, with an emphasis on their retention (Jokić, 2016). The challenge is to combine the information coming from different sources and which are selected in the database in the function of selling products and services CRM refers to the organization of data, that derives from business relationships on all bases between the bank and the client, and even beyond. Building a database is a gradual process (Rajević -Grujević, Radević, 2016). By placing the customer at the center, CRM is based on integrated market management, sales and customer service, as the key functions of banks that face daily customers. CRM is a strategic approach in building value for stakeholders, through the development of customer relationships (Marinković 2015). The bank should aim at the spirit of building teamwork. In the future, it is necessary to provide a high standard of quality and professionalism with the client as a central point. The goal starts with every employee, so accordingly, individual performance should include qualitative goals such as: integrity, kindness, responsibility, professionalism, knowledge, training, consistency, discipline and most other positive qualities.

\section{ANALYSIS OF CUSTOMER SATISFACTION AND LOYALTY TOWARDS BANKING PRODUCTS AND SERVICES IN MONTENEGRO}

\section{Research methodology}

The subject matter of the research of this paper is whether the customers are satisfied with the quality of banking services, and whether the satisfaction with quality affects customer loyalty towards the products and services of the banks whose services they use.

The aim of the paper is to determine where the dissatisfaction of clients lies regarding the available banking products and services; how banks should act to eliminate dissatisfaction and ensure, through customer satisfaction, that the client is loyal to a specific bank, which improves the quality of mutual relationship, and, consequently, the business environment as one of the factors of competitiveness.

The initial hypotheses of the paper read:

HO: The quality of banking operations has a crucial role in the process of building long-term relationships with consumers. Only satisfied clients are loyal clients, who make it possible for the bank to achieve long-term business goals and make profit.

H1: By improving the quality of products and services, the mutual relationship between the client and the bank is improved, as well as the business environment in which both parties take part.

H2: By improving the quality of banking services, a competitive advantage is achieved and the position of banks in the financial market strengthens, especially considering that banks operating in an environment which is rapidly changing.

Quantitative exploratory research was conducted on a sample of 300 respondents. For the needs of the research, a non-random convenience sample was used. The data were collected by the survey method, using a specially designed questionnaire. The survey was carried out on-site and on-line during the period August-September 2018 in the territory of Montenegro. A total of 350 questionnaires were distributed, out of which 300 or $85.71 \%$ of questionnaires were valid for processing, which is a high response for the purposes of this pilot survey. The questionnaire 
consisted of two parts: the first part concerned the collection of general data on respondents; while the second part covered a set of questions about the habits in the use of banking services, as well as about the satisfaction of users of banking services with both products and services, and the attitude of the staff of the bank who they come into contact with. Based on the processing of the questions, the findings were made that might help the managers to recognize the weaknesses of the bank's offer, and what customers need, how they are informed and where they see the deficiencies that can affect loyalty towards the products and services of the banking sector.

\section{Research findings}

It was found out by the descriptive statistics that $53.33 \%$ of female respondents and $46.67 \%$ of male respondents participated in the survey. As for the age, respondents belong to one of the five categories offered, with an equal number of respondents (100 of them or 33.33 per cent) belonging to the 18-28 age group and 29-38 age group, followed by respondents aged 39-48 with $15 \%$ The respondents aged $49-58$ accounted for $11.67 \%$, while the smallest percentage was of respondents over 59 years of age who accounted for $6.67 \%$. As regards educational qualification, the majority of respondents completed higher education, $45 \%$ of them, followed by respondents with completed secondary education who accounted for $31.67 \%$; while $15.67 \%$ of respondents have a college or university degree; followed by respondents with completed postgraduate studies, $7.66 \%$ of them; while there were no respondents among the surveyed ones who completed only elementary school. The respondents also provided answers about their employment status, with $59.33 \%$ of respondents who are employed; $27.67 \%$ of respondents are unemployed; while pensioners account for $13 \%$ of the sample.

Out of a total of 300 respondents, 260 of them responded that they used only the services of one bank, while 40 respondents confirmed that they used the services of more than one bank. Thus, we gained an insight that the use of the services of one bank is certainly an important and non-negligible piece of information that gives us a clear picture of the loyalty of users. Although, we must emphasize that in our informal conversation, the answer was mostly that "they do not want to deal with more banks, and that it is an unnecessary cost; that one bank is quite enough; and that they choose the best/most favourable one"

As the most important factor for the selection of the bank, respondents noted the amount of commission ( $25 \%$ of respondents or 75 respondents). The vicinity of the bank was crucial for 45 users (15\%). 16\% of the respondents mentioned the kindness of the staff as a crucial factor in using the services of the selected bank. The competence of the staff as a factor was indicated by 40 respondents $(14.67 \%)$. The quality of products and services was suggested by 70 respondents $(23.33 \%)$, while the speed of service provision, as the dominant factor in the decision regarding the selection of a bank, was indicated by 18 respondents (6\%). It can be concluded that the amount of commission and the quality of service are the two factors that stand out in the selection of the bank, and that the kindness and the competence of the staff, as well as the vicinity of the bank are equally and not less important factors.

The respondents provided answers about whether they were satisfied with the way of communication of the staff, and the findings showed that $40 \%$ of respondents were dissatisfied, the same percentage answered they were partially satisfied, while only $20 \%$ of respondents were completely satisfied with the way employees communicate with them. This piece of information is important for the management to bear in mind when training and appointing the front office clerks, because the significance of the front office staff is often overlooked when creating an impression about the service company itself. It is these $40 \%$ of partially satisfied ones that need to be won and turned into satisfied consumers, who will also turn into the category of loyal consumers. Frequently, a well-designed service or product has less value for consumers themselves if we encounter impolite staff. 
When questioned whether the respondents experienced some inconvenience in their selected bank, the majority of them - $217(72.33 \%)$ gave a negative answer, while 83 (27.67\%) respondents answered that they had suffered inconvenience in the bank. The reasons for the inconvenience were the following: a lack of interest and kindness of employees to obtain the right information; a poor explanation of technical terms; inadequate explanation about the user rights and benefits; new products; unkindness at the counter, etc.

As the ways of informing about the services of the bank, the highest percentage of respondents answered that they got informed through friends (30.67\% or 92 respondents), almost the same percentage was of those who got informed through advertisements -TV, newspapers, the web, the internet (25\%) and flyers (24\%). $12.67 \%$ (or 38 respondents) go directly to the bank to get information about the products and services, while $7.66 \%$ (or 23 respondents) use Call Centre services to get information about the products and services of the bank.

As much as $66.67 \%$ of respondents said they would not change their bank, while $33 \%$ of respondents were not satisfied with the services they receive in the bank whose clients they are, thinking that the services are of poor quality, that employees are not accurate, interested, etc. Even though a high percentage of respondents would not change their bank, respondents were given the opportunity to indicate which elements mostly affect the existence of dissatisfaction or what are the elements that customers themselves would recognize the banks could improve in order to increase customer satisfaction. As reasons for dissatisfaction, the users of banking services cited crowds at the counters ( 97 respondents), impolite staff (63 respondents), high commission (42 respondents), high default interest rates ( 44 respondents), short grace period (36 respondents) and too much paperwork (18 respondents).

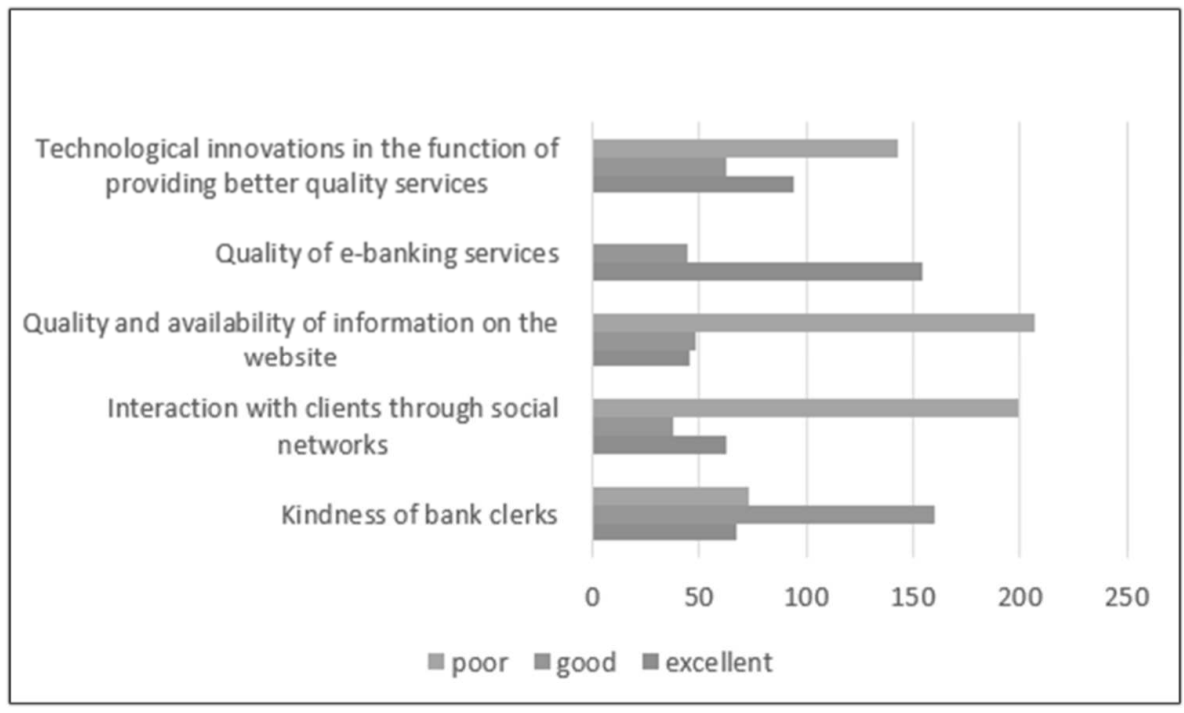

Figure 1. The evaluation of certain aspects of the bank's services

Source: Authors' analysis, September 2018.

The respondents were asked to evaluate certain aspects of the bank's services with "excellent", "good" or "bad". The clients rated:

- kindness of bank clerks ("excellent" - 67 respondents, "good" -160 respondents, "poor" 73 respondents)

- interaction with clients through social networks ("excellent" -63 respondents, "good" -38 respondents, "poor" - 199 respondents) 
- quality and availability of information on the website ("excellent" - 45 respondents, "good" - 48 respondents, "poor" - 207 respondents)

- quality of e-banking services ("excellent" -154 respondents; "good" - 44 respondents, while 102 respondents did not answer the question because they do not use e-banking services)

- technological innovations in the function of providing better quality services ("excellent" - 94 respondents, "good" - 63 respondents, "poor" - 143 respondents)

We can conclude that the respondents are particularly satisfied with the quality of e-banking, that the average rating was given for the kindness of the front office staff, while more than $50 \%$ of respondents gave a poor rating for technological innovations in the function of providing better quality services, the quality of the information available on the website, and the interaction with clients through social networks. All of the above aspects have the potential for improvement so that the clients could be more satisfied and, therefore, more loyal.

As for e-banking, 66\% (or 198) of respondents are users of this service, and they cited the elimination of waiting in branches, time savings and access at any time as the advantages of ebanking. Of the respondents who responded positively that they used e-banking services, $57.1 \%$ (or 113) confirmed that they used the services on a daily basis. It can be concluded that the use of e-banking is increasingly represented in our country, and that it is becoming a commonplace phenomenon. Most frequently, e-banking services are used for paying bills, online shopping, checking the account balance, money transfer.

$34.6 \%$ of respondents do not use e-banking services, and as the main reason they cited insecurity, insufficient information and lack of interest in this type of services.

In accordance with new trends in banking and bank networking, banking operations are performed faster, safer, in a better quality and uniform manner. In the banking sector, innovations have occurred and the e- banking and virtual banks are created. Innovations in banking operations primarily relate to the technology of payment operations and the transfer of funds. In line with these modern trends, the respondents were supposed to rate on a scale of 1 to 5 which of the offered services they use most: telephone banking, home banking, online banking, internet banking, or mobile banking.

Before the respondents even circled and gave their ratings, it was necessary to give them brief and clear explanations of what is meant by these five terms. Thus, it was established during the survey that respondents did not know the difference between the terms and often did not differentiate between them. After a brief introduction and provision of information, the respondents started to fill in the questionnaires. The average rating for telephone banking is 3.1; for home banking 3.8; online banking was given an average rating of 4.4; internet banking 4.8; mobile banking was rated with an average rating of 4 .

From the findings of the conducted research we can conclude that the respondents are loyal to the products and services of the selected bank, and that the amount of commission and the quality of the banking product and service are indicated as the main motive for selecting the bank. The competence and kindness of the staff, as well as the vicinity of the bank, are also important factors in selecting the bank. What the banks need to improve is the training of their front office staff. Clients expect from employees to be polite and professional, and it is precisely the incompetence of the staff that the clients are most complaining about and which causes the most dissatisfaction in the client-bank relationship. Kindness and professionalism of the staff must also be taken into account because the respondents answered that they most frequently got informed about the bank from the experience of acquaintances/friends, so the poor user experience or dissatisfaction can have a negative impact on attracting new clients. The research showed that clients were familiar with and were using innovations of contemporary trends in banking. Citizens in Montenegro, although still "shy", are increasingly using electronic and mobile banking services, 
which enable them to use the banking services in a convenient, fast, but, above all, in an efficient manner.

It can be concluded that this research has confirmed the set hypotheses. High quality banking plays a crucial role in building long-term relationships with consumers, as well as in building customer loyalty, especially considering that banks operate in an environment that is rapidly changing, so the basis for survival and generation of profit and competitive advantage can be seen in the strengthening and improving mutual relations between the client and the bank.

The contribution of the paper and the conducted research is reflected in the fact that the attention of marketing managers in banks is drawn to the fact that, in line with the modern concept, they must not rely on an independent and blanket assessment of customer satisfaction solely on the basis of sales results, but that the quantifying of the level of client satisfaction and placing it at the level of the business goal is as important as the financial result in the overall business success. Customer loyalty has always been one of the basic parameters of business success, and the client's satisfaction with bank products and services is a guarantee of long-term cooperation.

\section{CONCLUSION}

The sudden changes in the banking market and the volatility of the clients and the variety of choices influence the constant increase in the level of expectations in the next purchases or transactions. A successful bank brand is created in the way that users of banking products and services build long-term relationships with the bank based on trust, emotional experience and mutual understanding. In considering the relationship of satisfaction and customer loyalty, one should bear in mind that the information obtained in the satisfaction measurement process relates to a certain moment. On the other hand, the emotional response of the client after the purchased purchase changes over time under the influence of a number of factors. In cases of using banking services, the sense of satisfaction is variable and depends on the time cycle of using a particular service, such as, for example, the use of a long-term loan.

Fighting for clients with competition is never greater. So many banks and each of them offers the most favorable services to future clients, but also those who already is. The decision is on the clients; they choose the best services according to their personal preferences. It is up to the banks to keep the existing ones with good offers, to try to keep improving and technological advancement, because they will only be competitive, on that way, in a market that is "ruthlessly" for all participants on it.

From the findings of the conducted research we can conclude that the respondents are loyal to the products and services of the selected bank, and that the amount of commission and the quality of the banking product and service are indicated as the main motive for selecting the bank. What the banks need to improve is the training of their front office staff. Clients expect from employees to be polite and professional. Impoliteness of staff has proven to be the factor which causes the most dissatisfaction in the client-bank relationship. The survey has showed that clients are familiar with and are using innovations of modern trends in banking.

In modern conditions of banking operations, one of the most important tasks of management is customer satisfaction and their long-term retention. The priority of retaining the existing clients in relation to winning new ones is dependent, above all, on intense competitive pressures and high costs of winning new clients. The most effective way of retaining consumers is to build customer loyalty by continuously providing satisfaction and creating high costs of switching to other brands.

Trust and commitment are the most important determinants of loyalty of bank's clients. And while the absence of trust, most likely, will mean loss of partners, on the other hand, the positive 
performances of the partner, especially the quality of the delivered value, contribute to the strengthening of trust. Long-term trust between the bank and its clients creates commitment. Commitment, in addition to trust, is a key factor in the establishment of a quality relationship. Consumer commitment occurs as a result of the perceived difference between the costs and benefits (economic, social, status).

\section{REFERENCES}

Domazet, Ivana and Kovačević, Milica. 2018. „The Role of Green Marketing in Achieving Sustainable Development", International Monograph "Sustainable growth and development in small open economies ". Institute of World Economics, Budapest, Hungary, pp. 57-73.

Domazet, Ivana and Simović, Vladimir. 2015. „Creation of green jobs: Opportunity to reduce high unemployment in Western Balkans", Monograpf: Toward Green Economy: Opportunities and Obstacles for Western Balkan Countries, Xlibris LLC, USA. pp. 82-100.

Domazet, Ivana and Stošić, Ivan. 2013. "Strengthening the competitiveness of Serbian economy and the corporate market restructuring", Economic Analysis,Vol. 46, No 3/4, pp. 108-124.

Domazet, Ivana, Đokić, Ines and Milovanov, Olja. 2018. „The Influence of Advertising Media on Brand Awareness", Management: Journal of Sustainable Business and Management Solutions in Emerging Economies, 23(1):13-22.

Domazet, Ivana, Stošić, Ivan and Hanić, Azra. 2016. „New technologies aimed at improving the competitiveness of companies in the services sector”, International Monograpf „Europe and Asia: Economic Integration Prospects “. CEMAFI International, Nice, France, pp. 363-377.

Domazet, Ivana, Stošić, Ivan and Lazić, Milena. 2018. "Competitive Relations in the Aftersales Market of Major Home Appliances in Serbia”, Economic Analysis,Vol. 51, No 1/2, pp. 47-59.

Gaborović, Katarina. 2009. "Odnos prema klijentima", Blic, https://www.blic.rs/vesti/odnosprema-klijentima/lOhfew0, (28.06.2018.)

Hanić, Hasan and Domazet, Ivana. 2012. „Specifičnosti marketinga finansijskih organizacija”, Marketing 43(1): 3-14.

Hanić, Hasan, Domazet, Ivana and Drašković, Božo. 2011. „Razvoj i upravljanje odnosima sa klijentima u industriji finansijskih usluga“, Poslovna ekonomija, 9(2):131-150.

Hill, Nigel and Alexander, Jim. 2006. Customer Satisfaction and Loyalty Measurement, Gower Publishing Limited, Hampshire.

Jokić, Mira. 2016. "Odnos sa klijentima, SSE business travel i meating", https://www.seebtm.com/odnos-sa-klijentima-customer-relationship-management-crm/ (28.06.2018)

Jovićević, Ratimir and Žugić, Jelena. 2018. Marketing u savremenom bankarstvu, Univerzitet Mediteran, Podgorica

Kotler, Philip. 1999. Upravljanje marketingom, Informator, Zagreb

Maričić, Branko. 2005. Ponašanje potrošača, Ekonomski fakultet, Beograd

Marinković, Veljko. 2012. Marketinski aspekti satisfakcije i lojalnosti, Ekonomski fakultet, Univerzitet u Kragujevcu, Kragujevac.

Raičević, Milica and Medenica-Mitrović, Dijana. 2018. "A comparative analysis of the corporate identity of banks in Montenegro" the paper presented on International Symposium on Business and Economics, GSI \& UM, 5-8 September 2018, Podgorica, Montenegro

Raičević, Milica and Medenica-Mitrović, Dijana. 2018. "Measurement of the Quality of Banking Services in Montenegro by applying the SERVQUAL model", Book of Proceedings of 14th International May Conference on Strategic Management - IMCSM18 Edition: IMCSM Proceedings; Volume XIV, Issue (2) Bor, pp 111-123

Raičević, Milica and Medenica-Mitrović, Dijana. 2018. "Quality of Operations for the Purpose of Competitive Adventage of the Bank", paper presented on International Scientific and Expert Conference "Economic Development and Competitiveness of European Countries: AchievementsChallenges-Opportunities”. Novi Sad, October 3-5, 2018. 
Raičević, Milica and Medenica-Mitrović, Dijana. 2018. „Social Responsibility of Banks in the Function of Comparative Advantage on the Market", Economic Analysis Vol 51 No 1-2, Beograd, pp 92-102

Raičević, Milica and Žugić, Jelena. 2017. „Značaj i uloga integrisanih komunikacija u savremenom bankarskom marketingu“, Medijski dijalozi - Časopis za istraživanje medija i društva, Vol 10, No 29, Novembar 2017, str. 255-267

Raičević, Milica and Žugić, Jelena. 2018. "Models of measurement of quality of banking services", the paper presented on International Symposium on Business and Economics, GSI \& UM, 5-8 September 2018, Podgorica, Montenegro

Rajevac- Grujić Ljiljana and Radević Ivan. 2016. Savremeni modeli pristupa klijentima banke, Stručni rad, Univerzitet Union, Nikola Tesla, Beograd.

Rajola, F. 2004. Customer Marketing Management, Organizational and Technological Perspecitve, New York, USA.

Raspor, Anderej, Medenica-Mitrović, Dijana, Lacmanović, Darko and Raičević, Milica. 2018. "Impact of Tipping on Workers' Motivation: Case Study from Montenegro", Global Business Conference 2018 Proceedings, Developing new value-creating paradigms, pp 195-207

Vasiljev, S. 1999. Marketing principi, Birografika, Subotica

Veljković, Saša. 2009. Marketing usluga, CID Ekonomskog fakulteta u Beogradu.

Zelenović, Vera. 2015. Marketing u bankarstvu, Proleter a.d. Bečej, Subotica. 